\title{
Poetics and politics: Bikini Atoll and World Heritage Listing
}

\author{
Steve Brown, Office of Heritage and Environment, NSW, Australia
}

\begin{abstract}
'No literary work of imagination could create a more monstrous evil.' (Zinn 2010:29)
"Social Poetics': an approach that opens up the tensions between official models of national culture and the lived experience of ordinary citizens.' (Herzfeld 1997)
\end{abstract}

\section{Bombs and bikinis}

It is strange the way that 'bikini' simultaneously references nuclear test site and itsy-bitsy bathing costume. Yet the two are intimately connected - le bikini was revealed at a public pool in Paris on 5 July 1946, four days after the globally publicised Able Atomic Test explosion was unleashed at Bikini Atoll, Republic of the Marshall Islands (Figure 1). The atoll's name was appropriated for le bikini, a garment promoted as a vision of the vestiges (meaning traces, remnants or relics in French) of clothing that would remain after experiencing an atomic explosion (Cameron 1970 in Davis 2005a:615-616). Ironically, the bathing costume would, during the 1950s, come to be associated with untouched and romanticised sun-drenched tropical islands.

The original Bikini translates from Marshallese as 'the lands of many coconuts' and refers to the huge groves of trees visible on the horizon to ancient mariners as they approached the atoll islands (Jack Niedenthal pers. comm., 2011) (Figure 2). The reality of humanly-willed catastrophe of bomb testing on Bikini Atoll between 1946 and 1958 was the deaths of, and ill-health effects for, Marshallese, American and Japanese people. In addition, all of the original coconut groves on the twenty three surviving atoll islands were destroyed.

On Sunday 1 August 2010, during the 34th session of the World Heritage Committee (in Brasília), Bikini Atoll Nuclear Test Site, Republic of the Marshall Islands (RMI), was inscribed on the World Heritage List as an outstanding example of a nuclear test site and as a source of globally significant cultural symbols and icons of the twentieth century (Decision 34COM 8B.20, World Heritage Committee 2011). This act, I suggest, was simultaneously poetic and political: the property was at once imagined as wasteland (a landscape ravaged and made dangerous by technologies of the modern era) and wonderland (a remote landscape conceptualised as deserted, exotic and earthly paradise), a subversive space coopted as 'heritage' by both global and local actors. The UNESCO World Heritage project, driven by a credible and representative world heritage ethos, sought out the remote atoll of Bikini for listing. The global attention listing brought was in turn conscripted by Bikinians displaced from their homeland to further their goals of being heard, recognised and supported. 


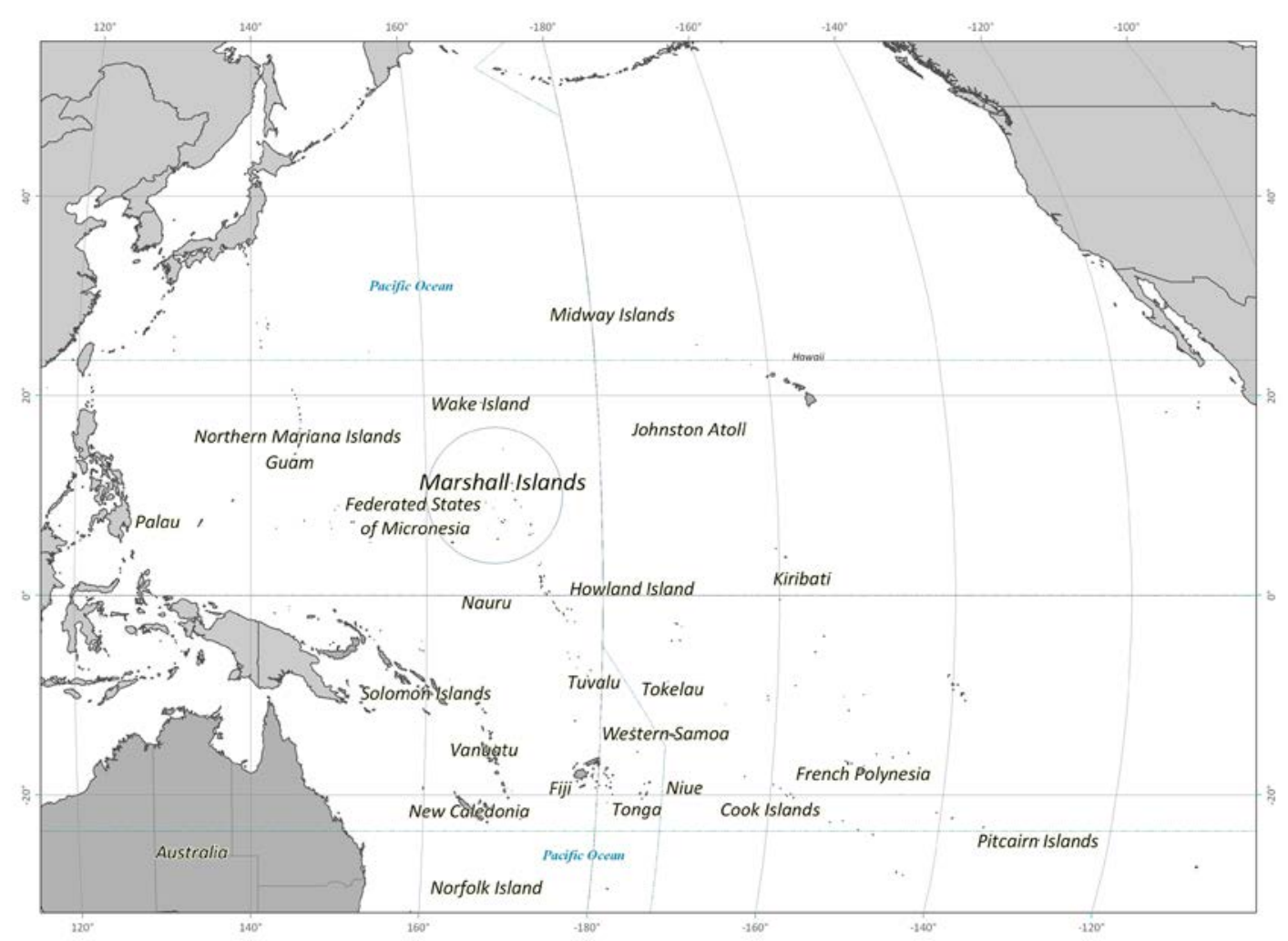

Figure 1. Map of Pacific region, showing location of the Marshall Islands.

Source: RMI 2009.

In the case of Bikini Atoll there is a cultural engagement between global and local in world heritage listing that comprises complex processes of creative cooptation in political, economic, and administrative practices (Hertzfeld 1997:3). There is an element of social poetics, a term used by the anthropologist Michael Herzfeld, in the way that local Bikinian people find advantage through engaging with the world heritage project and global heritage practice. The loss of homeland through nuclear testing is at the heart of a struggle to be supported; a struggle that is necessarily a part of Bikinian identity.

However, at its core, the history and heritage enlisted to raise the atoll to world heritage status - the 'technical ensemble' of bomb-testing along with the associations with globally significant cultural symbols and icons is not strictly the history and heritage of the Bikinian people. The Indigenous inhabitants of Bikini Atoll were shipped out to make way for the United States' nuclear test program of 1946 and 1954-1958. Radioactive contamination has meant that the Bikinians have never been able to permanently return to their homeland. Nuclear testing became Bikinian heritage, a heritage not of their making.

In this paper I explore the complexities of the nuclear test period heritage of Bikini Atoll and its management. I describe the parallel, yet slippery, universes of local and global in the recognition, protection and management of Bikini's cultural landscape/seascape. I argue that entangled local and global management regimes have initially established a mutually beneficial arrangement for UNESCO and for the Bikinian community. However, a possible future resettlement of the atoll has a potential to destabilise this relationship because of the tensions likely to be created between the rights of Bikinian people to reoccupy their homeland and the inevitable impacts on the universal values of the property. 


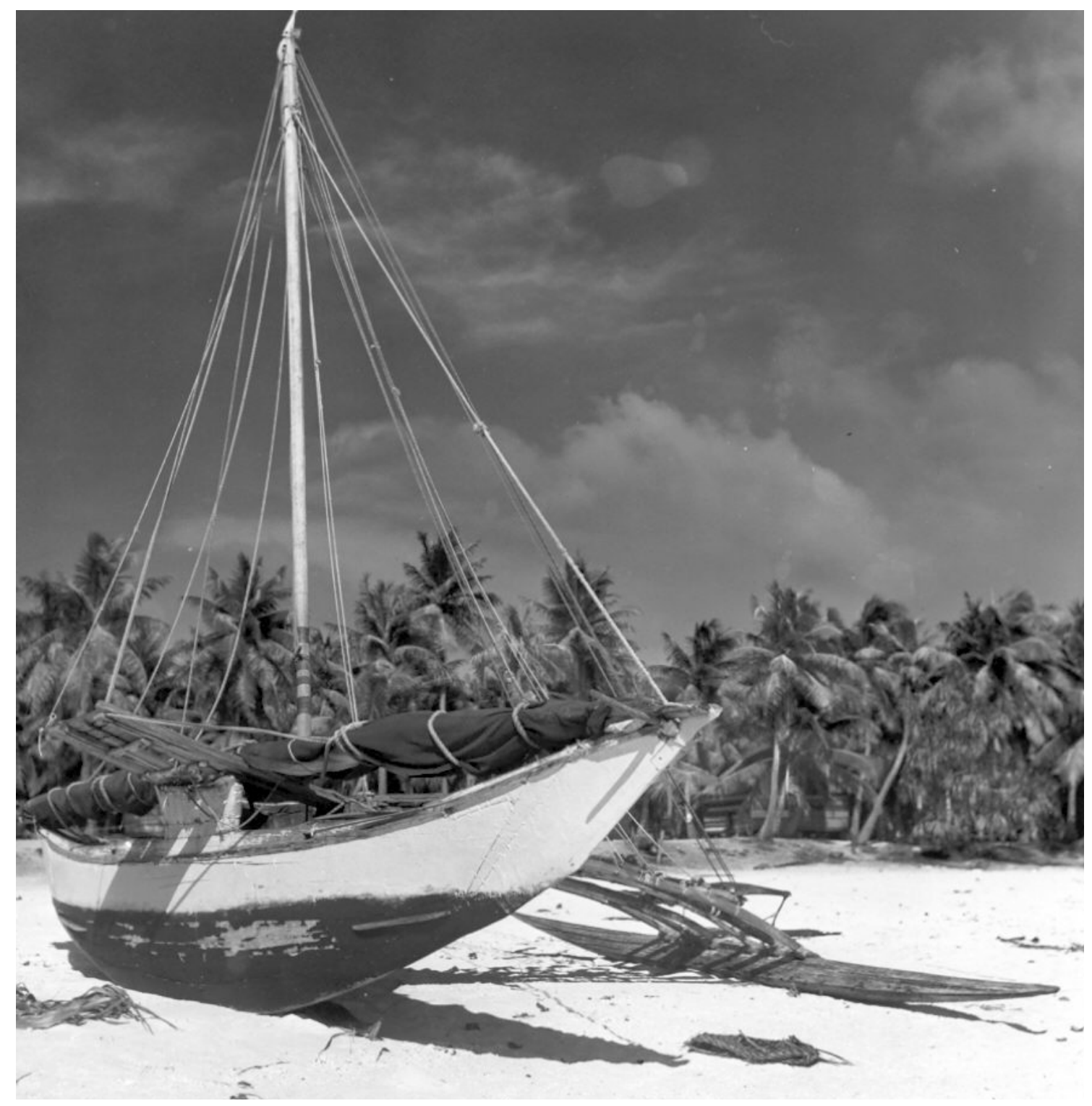

Figure 2. Boat and groves of coconut trees, Bikini Atoll.

Source: US Government, 1946.

The historical context is that, after atomic bombs were dropped on Hiroshima and Nagasaki in 1945, nuclear testing in the Pacific took place almost continuously between 1946 and 1996 (Smith 2007). At each test location Indigenous populations were displaced. The USA chose Bikini Atoll as the site for the first major atomic experiments. Two atomic bomb tests ('Operation Crossroads') were undertaken at the atoll in July 1946 and a further twenty-one nuclear (hydrogen) bomb tests between 1954 and 1958 (RMI 2009:29-44).

The history of nuclear testing at Bikini Atoll, beyond the summary above, is not detailed in this paper. Anita Smith (2007) has written an overview of colonialism and the bomb in the Pacific. There are a number of descriptive narratives of the Marshall Islands tests (Kiste 1974; Weisgall 1994; Carucci 1997; Simon 1997; Barker 2004; de Groot 2006), several outstanding documentaries (e.g. Academy Award nominated Radio Bikini [Stone 1988]), and contemporary published accounts (e.g. Bradley 1946) as well as newspaper coverage analysis (Keever 2004) and popular magazine stories (Davis 2005a). There is also a huge archive of primary source material on the testing, including declassified US government 
documents and film. There are a number of accounts of the Bikinian relocation and forced migration story (Weisgall 1980; Niedenthal 1997), including oral histories with Bikinian Elders (Niedenthal 2001), anthropological studies (Mason 1950, 1954) and recent articles that contextualise the Bikinian's historical experience read from different, including geographic and folkloric, perspectives (Davis 2005a, 2005b; McArthur 2008). A description of the terrestrial material traces of nuclear testing on Bikini Atoll can be found in Brown (2013).

\section{Indigenous peoples, heritage and free, prior and informed consent}

The common understanding of the right to free, prior and informed consent is that consent should be given freely, without coercion, intimidation or manipulation (free); sought sufficiently at all stages, including from inception to final authorization and implementation of activities (prior); based on an understanding of the full range of issues and implications entailed by the activity or decision in question (informed); and given by the legitimate representatives of the Indigenous peoples concerned. (UNPFII 2011:7[34])

\section{Sunday 10 February 1946}

On this particular Sunday after church, the United States military governor of the Marshall Islands, Commodore Ben H Wyatt, addressed the assembled Bikinian community. Wyatt asked if they were willing to leave their atoll temporarily so that the United States could begin testing atomic bombs 'for the good of mankind and to end all World Wars'. Juda, the iroij or leader of the Bikinian people '.. after much confused and sorrowful deliberation among his people' (Niedenthal 1997:29), announced: 'We will go believing that everything is in the hands of God.' There was no signed agreement. Commodore Wyatt reported by cable: '... their local chieftain, referred to as King Juda, ${ }^{1}$ arose and said that the natives of Bikini were very proud to be part of this wonderful undertaking' (Weisgall 1994:107).

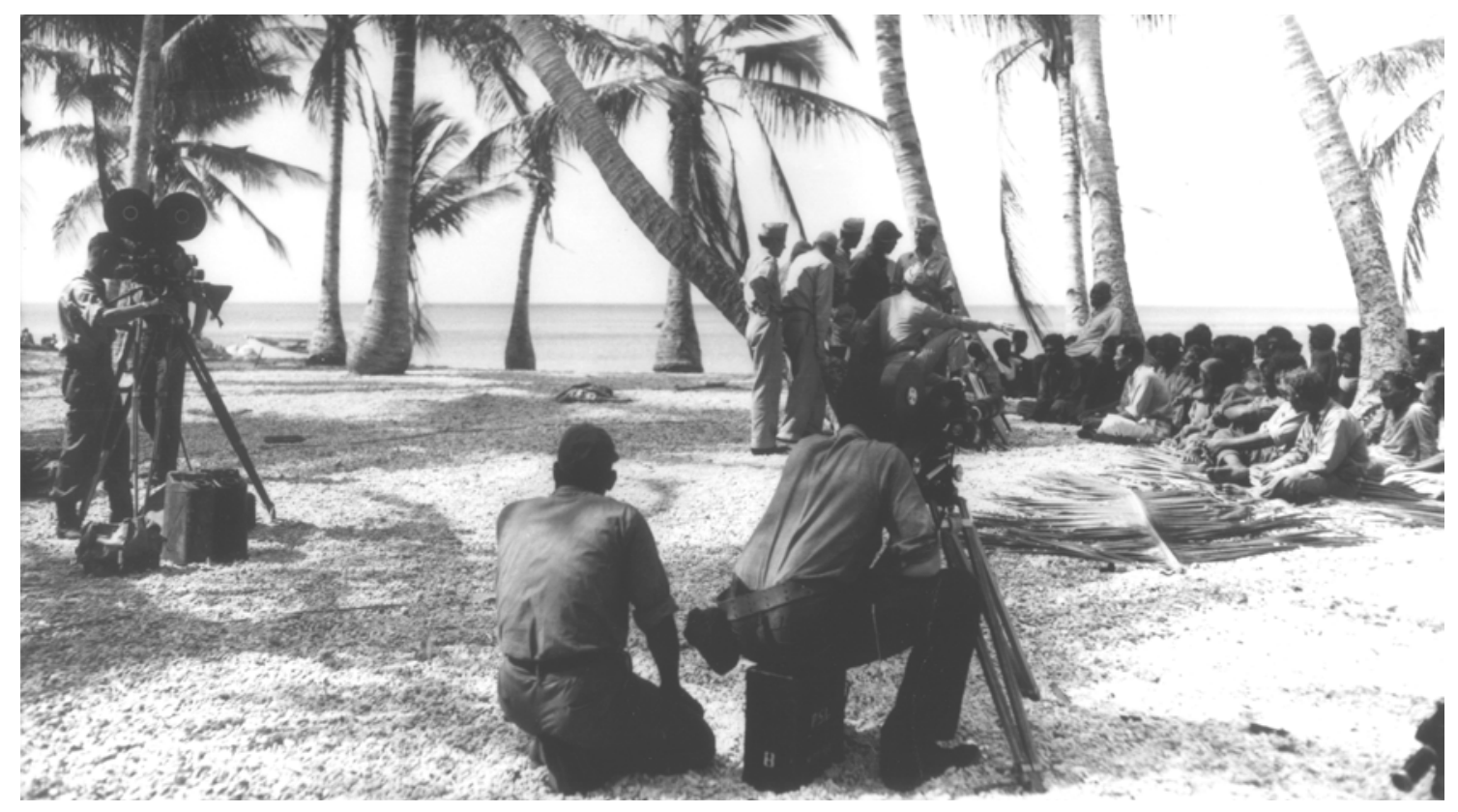

Figure 3. Filming of staged re-enactment of Commodore Wyatt addressing the assembled Bikinian community, 6 March 1946.

Source: US Government, 1946.

1 Tobin (1953:20-25) provides an account of how the use of the term 'King' from this time was read by Bikinians as official recognition of Juda's sovereignty on Bikini by the American government. This position strengthened the case for Juda as the 'rightful ruler' over a rival's claim to be paramount chief. 
On 6 March 1946, Commodore Wyatt staged a filmed reenactment of the February 10 meeting in which world peace was exchanged for homeland (Figure 3). The next day, the 167 Bikinians inhabiting the atoll along with their belongings were shipped out (Figure 4) to Rongerick Atoll, a place believed to be inhabited by evil spirits. Two atomic bomb tests were undertaken as part of Operation Crossroads in July 1946. Juda was brought back to Bikini Atoll by the US to witness the explosion of the second and larger bomb test, the Baker Atomic Test on 25 July 1946 (Niedenthal 2001:3).

No one today would argue that the homeland for world peace transaction reflected free, prior and informed consent on the part of the Indigenous population. Anthropologist JA Tobin (1953:8) suggested that, in 1946, for the Bikinians there was an historical conditioning to 'obedience' after a quarter of a century of autocratic Japanese rule. Thus it seems reasonable to surmise that negotiating with men in military uniform like Commodore Wyatt would have been intimidating, regardless of the colonialist context or power dynamic of the engagement (cf. Smith 2007:56, 69).

Tobin's 1953 report emphasises the firm belief held amongst the Bikinian people that their removal was only temporary, and that they would be returning to their ancestral home, a return that the Bikinians believed (in 1953) was imminent. In this regard Tobin's findings reflected those expressed in anthropological reports previously provided to the US Trust Territory administration (e.g. Mason 1950; Drucker 1950 in Tobin 1953:13-15). Tobin had been part of a mission to Kili Island in January 1951 to negotiate 'the release of rights to Bikini', which the Bikinian Council 'unequivocally and unanimously refused to consider' (Tobin 1953:17).

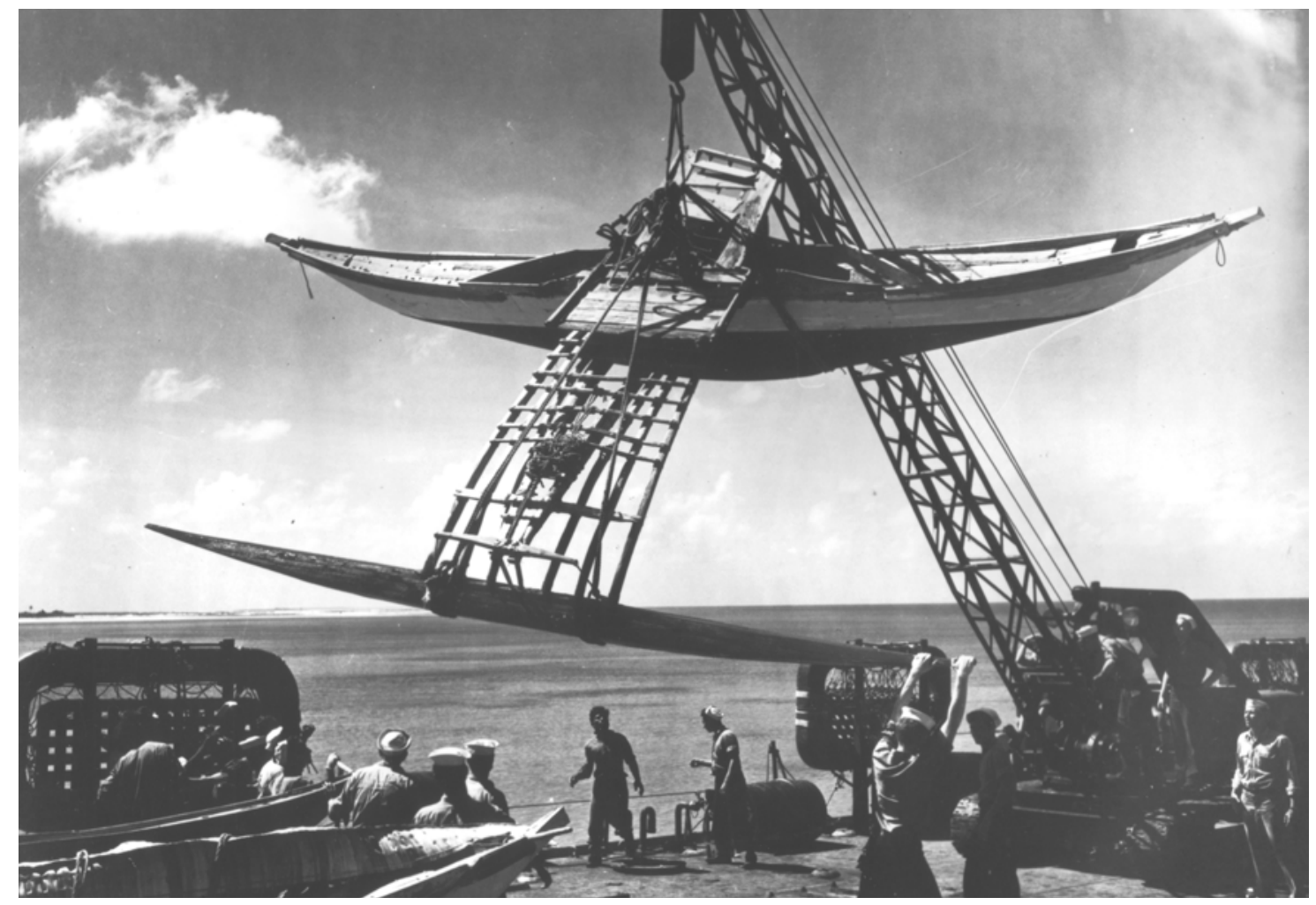

Figure 4. Loading a boat onto US naval vessel for departure from Bikini Atoll, March 1946.

Source: US Government, 1946. 
Bikinians today continue to believe that a return to their homeland will happen. The memory of Sunday 10 February 1946, now some 67 years distant, is forever inscribed on the flag of the people of Bikini - Men Otemjej Rej Ilo Bein Anif('everything is in the hands of God') (Niedenthal 2001:175).

\section{Wednesday 29 June 2011}

On this day representatives of the United Nations Permanent Forum on Indigenous Issues (UNPFII) and of the International Work Group for Indigenous Affairs (IWGIA) addressed the $3^{\text {th }}$ session of the UNESCO World Heritage Committee in Paris. The representatives voiced their concerns about making the implementation of the World Heritage Convention (UNESCO 1972) consistent with the United Nations Declaration on the Rights of Indigenous Peoples (United Nations 2007).

In May 2011, UNPFII called on UNESCO, IUCN, ICOMOS and ICROM ' $\ldots$ to review current procedures and capacity to ensure free, prior and informed consent, and the protection of Indigenous peoples' livelihoods, tangible and intangible heritage' with regard to World Heritage Listing (UNPFII 2011:8[36]). These concerns are expressed in a 'Joint Statement on Continuous violations of the principle of free, prior and informed consent in the context of UNESCO's World Heritage Convention' (IWGIA 2011). The joint statement was submitted to UNESCO's World Heritage Centre and the Bureau of the World Heritage Committee. The issues are encapsulated in the following extract from the joint statement:

Last year, at the World Heritage Committee's 34th Session in Brasilia (25 July-3 August 2010), the Committee inscribed two sites on the World Heritage List although questions had been raised regarding Indigenous peoples' participation in the nomination processes and their free, prior and informed consent: the Northwest Hawaiian Islands Marine Monument ('Papahānaumokuākea Marine National Monument') and the Ngorongoro Conservation Area in Tanzania. The latter was re-inscribed as a cultural World Heritage site, because of its significance as an archaeological site, not because of the significance of the Maasai culture. We are concerned that the Committee's recognition of only the archaeological values, and not the living cultural values of the Indigenous residents, may exacerbate the already existing imbalances in the management framework for the Ngorongoro Conservation Area and lead to additional restrictions on the livelihoods of the Indigenous residents and further infringements on their rights.

In response to the joint statement and to the representations of the global Indigenous NGOs, the World Heritage Committee encouraged States Parties to respect the rights of Indigenous peoples and local communities and involve them in World Heritage nomination and management processes (Decision 35COM 12D, World Heritage Committee 2011).

\section{Local rights and global interventions}

The actions that took place on 10 February 1946 on Bikini Atoll and on 29 June 2011 in Paris illustrate aspects of the changing order of global politics with regard to the power of Indigenous people. The Cold War testing of nuclear devices in the Pacific in the second half of the twentieth century was part of a larger and longer history of imperialism in the region, though also a period when Pacific island nations gained independence (Smith 2007). In the case of the Marshall Islands, where the United States continues to occupy Kwajalein Atoll for military projects in return for rent payments, there is a complex interplay between independence from, and dependence on, the United States following the signing of the Compact of Free Association 1986 (US Department of Interior 1986), which was renewed in 2003 for 20 years. 
Akin to the Compact of Free Association, the creation of the UNESCO World Heritage Convention (WHC) in 1972, and its subsequent operation (particularly through the 1970s and 1980s), is viewed by some commentators as a 'neo-colonial' project. This is illustrated for example in the way the WHC promotes the idea of 'universality', a concept deeply rooted in European cultural tradition (Cleere 2001:24), in its adoption of the notion of Outstanding Universal Value (OUV). Laurajane Smith, for example, argues that the concept of universality is 'deeply rooted in the process of colonization and imperial expansion and assumptions about the cultural and technological evolutionary achievements of the West' (Smith 2006:99). To give credit to the work of the WHC over forty years of its operation, it has responded actively to various challenges (e.g. a credible and representative world heritage list, discussed below) and evolution in understandings of the meanings of the idea of heritage (e.g. including intangible heritage - Blake 2009:66).

The global history of colonialism and neo-colonialism is inextricably enmeshed with issues of Indigenous rights. The story of Bikini Atoll and its inhabitants is a part of this history, a situation where the islanders were forced to leave their homeland, a place where Bikinian myth, history and genealogy, and identity are inscribed into landscape (McArthur 2008:264).

\section{Local and State: Indigenous heritage and 'conserving' culture}

\section{Traditional system}

Anthropologist Leonard Mason documented aspects of the Bikinian matrilineal social structure following their relocation of the community to Rongerick Atoll in March 1946 (Mason 1954; Mason in Niedenthal 2001:v-vi). At that time there were eleven Bikinian matrilineages (among a population of 196 people), each with an alap ('hereditary head') of which Juda was the head of the top matrilineage. The system changed after this time, and for example by 1957 land on the 81 ha island of Kili was divided amongst twenty kin or 'family groups' (bamle) (Mason in Niedenthal 2001:vi).

Concerned that knowledge of the traditional land system would be lost, as well as to get ready for a future contamination clean-up of the atoll prior to a re-settlement, a delegation of Bikinians returned in 1987 to re-establish the traditional land boundaries on Bikini ( $237 \mathrm{ha})$ and Enue (125 ha) islands. The 'parcels of land' (weto) run in 'strips' across the islands extending from the lagoon to the ocean sides (Holmes and Harver 1989) (Figure 5). Bikinian Jukwa Jakeo (in Niedenthal 2001:110) said of the re-inscribing process:

The technical difficulties that we experienced in our attempts to re-establish the boundaries stem from the fact that all the natural surroundings and the markers that we used to delineate the land partitions are now gone. They were destroyed by the U.S. government and all of their atomic bomb testing. Today, when we draw the lines, we are using estimations only.

Within the context of the Indigenous customary land tenure on Bikini Atoll, it is clear that the terrestrial material traces of testing are located on land that is privately owned; and the impact of nuclear testing (land clearance, radioactive contamination) effects all land and landholders. Needless to say, the Bikinian customary land tenure system does not provide protective mechanisms for USA-created nuclear test features, heritage features that were not created by Bikinians but none-the-less are the property of customary landowners. ${ }^{2}$

2 There is a gendered element to this situation. The Bikinian social system is a matrilineal one yet the delegation to re-establish land boundaries on Bikini Island in 1987 comprised elderly men (Niedenthal 2001:110). The way gender roles work in land ownership, and in the ownership of the nuclear test structures, is beyond the scope of this paper. I confess to having little knowledge on this topic. 


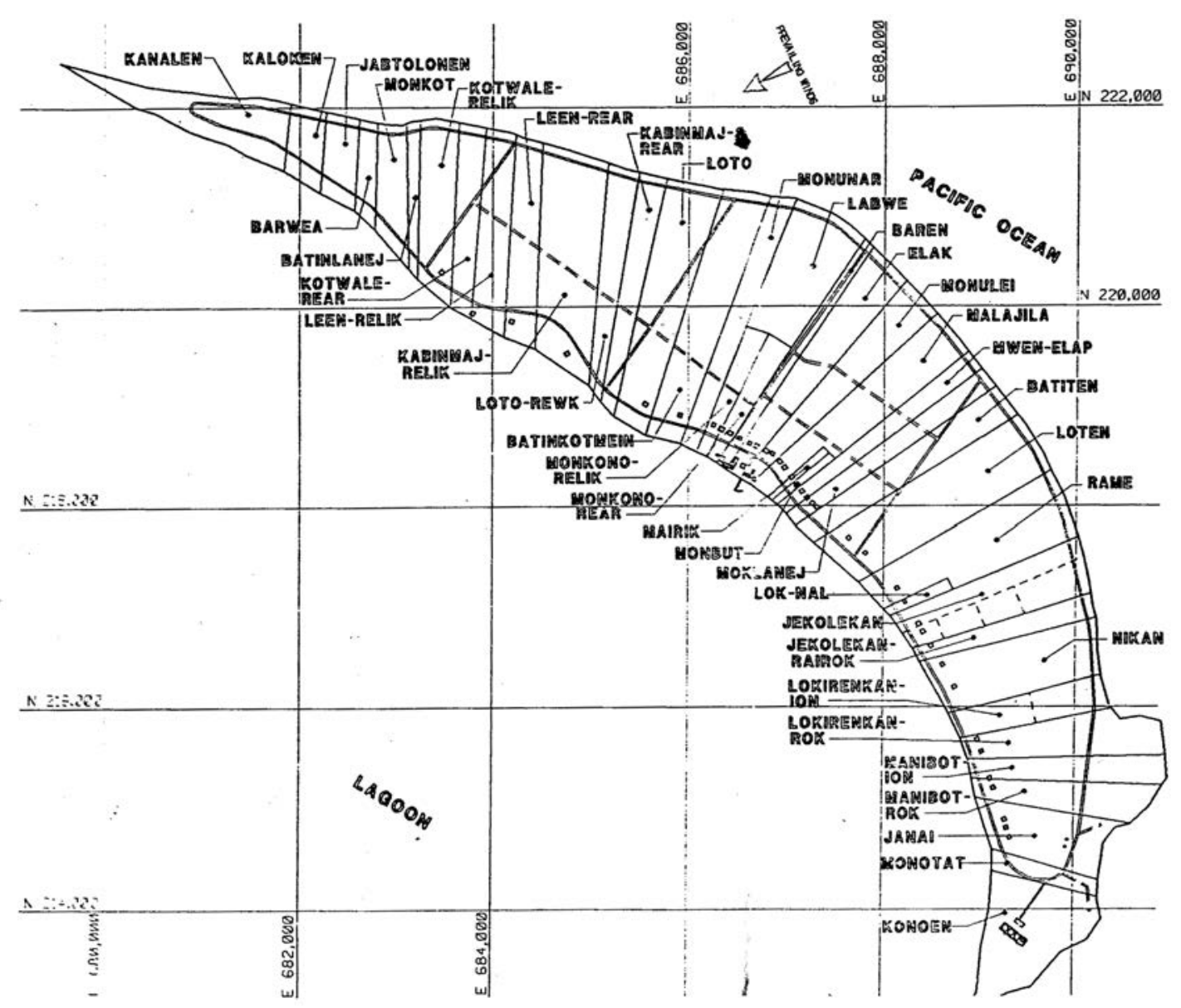

Figure 5. Diagram showing re-established land boundaries (weto) on Bikini Island.

Source: Holmes and Harver, 1988.

\section{Legal system - State and local}

The Republic of the Marshall Islands Historic Preservation Act of 1991 and five regulations relating to this Act, largely based on USA laws, are the basis for managing cultural heritage at a national level in the RMI (Spennemann 2000). The legislation is administered through the Historic Preservation Office (HPO) which has the primary responsibility for identification, recording, protecting and preserving the tangible and intangible cultural properties of the RMI. No 'cultural and historic property' for Bikini Atoll is currently included in the RMI National Register of Historic Places. It would appear therefore that historic sites, both on-land and submerged, relating to nuclear testing at Bikini Atoll are not protected under the Historic Preservation Act of 1991. However, protection is afforded to 'artefacts' removed from the atoll which may be seized if they are believed to be prohibited for export (Spennemann 2000).

The constitution of the RMI establishes a system of local government [Constitution of the Republic of the Marshall Islands, Article IX, Section 1(2)]. The Kili-Bikini-Ejit Local Government (KBE LG) may make ordinances for the area in its jurisdiction, which extends to the sea and the seabed of the internal waters of Bikini Atoll and to the surrounding sea and seabed to a distance of five nautical miles. The KBE LG has made ordinances regarding access to Bikini Atoll, illegal fishing, fish harvesting levels, wreck diving requirements and prohibiting removal of objects from Bikini lagoon (Baker 2010:13). 
Since Indigenous customary land tenure on Bikini Atoll, like much of the Pacific, is 'extremely privatised', archaeologist Richard Williamson (2001:44) argues that within the RMI, '(w)ith few exceptions, the landowners, and not the government, have absolute control of land'. Williamson further argues that preservation of 'historic sites' - sites relating to colonial and military occupation - must therefore come through education rather than legislation.

\section{Nuclear fleet}

The complex interplay of history, ownership and heritage management regimes is illustrated in the case of the 'nuclear fleet' at Bikini Atoll. As part of Operation Crossroads in 1946, eighty-eight 'target' vessels were laid out across Bikini's central lagoon by the US in order to assess the effects of two atomic tests - Able and Baker. Twenty-one vessels were sunk in the $60 \mathrm{~m}$ deep lagoon with most clustered in the shallow crater formed by the Crossroads Baker Test. The Compact of Free Association between the Government of the United States of America and the Government of the Republic of the Marshall Islands 1985 (Article 177) transferred ownership of all 'sunken vessels' (as well as 'cable'), including liability resulting from salvage operations, from the USA government to the people of Bikini (Spennemann 1990:22; Delgado et al.1991). Under the agreement, studies of the sunken fleet were conducted by the USA to assess environmental hazards (leaking fuel, structural condition of the ships, safety of live bombs and residual radioactivity) as well as an assessment of historic significance.

The US National Park Service (NPS) undertook an historic and archaeological assessment of nine vessels in 1989-90, focussing on the aircraft carrier USS-Saratoga, though also documenting to a lesser degree the battleships HIJMS Nagato (Japan) and USS-Arkansas and the US submarines Pilotfish and Apogon, as well as the German cruiser Prinz Eugen, which had been scuttled at Kwajalein Atoll after Operation Crossroads (Delgado et al.1991; Delgado 1996). All vessels were assessed to be historically and archaeologically significant and the establishment of an 'archaeological park' was recommended. The survey report (Delgado et al.1991) also outlines the risks associated with the detonation of unexploded ordnance and fuel associated with the sunken ships.

Between 1996 and 2008, the KBE LG established and operated a commercial diving enterprise, Bikini Atoll Divers, in part to provide an economic base for a possible future resettlement of Bikini Atoll. Typically the tourism operation ran from late April to November and involved groups of up to 12 divers visiting the atoll for a week, with the annual number of recreational divers numbering between 200 and 250. In addition to the diving, fishing and a tour of the atoll, the tourism operation emphasised the telling of Bikinian history. Documentary films as well as lectures were presented to the participants in order to share and perpetuate a local nuclear story.

In order to safeguard the moveable traces of the wrecks, the KBE LG enacted laws that made the removal of 'artefacts' from the sunken vessels illegal. Enforcement of the KBE LG's Ordinance No. 2-1996, relating to the removal of artefacts from the sunken vessels, is undertaken with regard to visitors in a number of ways. Firstly, access to Bikini Atoll is controlled by the KBE LG. Secondly, the 'Liability Release' form that all divers were required to sign made it clear that the taking of artefacts from any of the vessels is illegal and subject to a fine of US \$5,000 for each artefact taken. The divers were required to also give permission to have their belongings searched. Thirdly, Mr Jack Niedenthal (Trust Liaison Officer, KBE LG) monitors E-bay, using 'Bikini' as an identifier, for any items appearing for sale.

In 2008 the KBE LG Council closed the Bikini Atoll Divers operation due to local airline reliability issues, soaring energy costs and US stock market conditions that impacted the local government 
budget. In 2011 the Local Government signed an agreement with a commercial operator (Indies Trader Marine Adventures) that would permit the commercial operator to operate their live aboard vessel, the Windward, on Bikini Atoll. The diving operation recommenced in June 2011.

The engagement of the Bikinians with the sunken nuclear fleet has served a number of purposes. As well as the economic and political benefits (touched on above), the Bikini Atoll Divers enterprise has enabled Bikinians to continue to revisit the atoll and maintain physical and spiritual connections. The project has also built local Bikinian capacity in cultural heritage management, largely undertaken with the support and assistance of international partners. In addition to the US National Park Service documentation of the sunken vessels (Delgado et al.1991), James Delgado has provided ongoing management and interpretation advice. Partnerships are proposed to monitor the ships and artefacts on them (with James Cook University and the Western Australian Maritime Museum, Australia) and to develop interpretation materials for the sunken vessels (Indiana University, USA).

The engagement of Bikinians with the nuclear fleet has a dimension of social poetics with regard to the way in which cultural heritage is recognised and managed in the Marshall Islands. While the focus of the RMI national heritage regime is on documenting and preserving traditional Marshallese culture, the Bikinians have 'sacrificed' a considerable amount of traditional knowledge (e.g. lagoon fishing skills, local ecological familiarity) as a result of nuclear testing. Bikini Atoll Divers arose from a conscious engagement with the atoll's nuclear test history, an engagement that provides benefits that include re-telling the contemporary 'nuclear nomad' story (cf. Niedenthal 1997).

\section{Conservation measures}

The present state of conservation of the material traces of nuclear testing is variable. The sunken ships and most of the bunkers are generally intact and well preserved, though are gradually deteriorating. For example, the bridge on the USS Saratoga is gradually collapsing and subsiding (Jack Niedenthal pers. comm., 2009); the 'Assembly Building' on Eneu Island, a large (c. 32 m x 15 m) wood framed and iron clad structure, was demolished in the early 1990s as it was considered unsafe; and terrestrial structures are continually impacted by tropical vegetation (cf. Spenneman and Look 2006).

No active conservation measures, including maintenance work, are being undertaken on the sunken ships, bunkers and other nuclear test period physical remains. The World Heritage Nomination Dossier (RMI 2009:63) and Bikini Atoll Conservation Management Plan (Baker 2010) make the point that the deterioration of the sunken ships and bunkers contribute to the distinctive character of the elements. These documents take a position that physical conservation works are not required to retain the OUV of the property. In general the current management system of 'do nothing' is effective, in part because of the lack of threats, the robustness of the tangible cultural heritage and the remoteness of the nominated property. However, there remains a need to document and monitor the nuclear test features, most likely achieved with the support of international partners.

\section{UNESCO's credible and representative world heritage ethos}

The nomination of Bikini Atoll is in large part a consequence of a process to address the underrepresentation of properties in the Pacific Islands Region on the World Heritage List. A series of World Heritage Global Strategy meetings for the Pacific Islands Region, commencing in 1997 (Smith and Jones 2007:6-13), have been undertaken as part of a process to develop a representative, balanced and credible World Heritage List (World Heritage Committee 1994; UNESCO World Heritage Centre 2004, 2008). 
In 2007, ICOMOS published a thematic study, Cultural Landscapes of the Pacific Islands (Smith and Jones 2007). The publication was prepared to support possible nominations for World Heritage status through a summary of available evidence. Bikini Atoll is presented as a case study, emphasising the nuclear testing history and in particular the ships sunk in the lagoon as part of the 1946 atomic bomb tests (Smith and Jones 2007:86-87). The January 2009 Nomination Dossier (RMI 2009) for Bikini Atoll was prepared with the support of an 'International Preparatory Assistance Grant' from the World Heritage Centre in 2006.

On Sunday 1 August 2010, during the $34^{\text {th }}$ session of the World Heritage Committee (in Brasília), Bikini Atoll Nuclear Test Site, Republic of Marshall Islands, was inscribed on the World Heritage List as an outstanding example of a nuclear test site and as a source of globally significant cultural symbols and icons of the $20^{\text {th }}$ century (Niedenthal 2011). The bikini swimming costume is one such 'pop culture icon' (RMI 2009:52).

World Heritage listing has (re)materialised and (re)imagined Bikini Atoll by privileging 12 years of the atoll's history (1946-1958). The UNESCO synthesis of OUV recognises the Bikinian people's experience as part of the nuclear narrative of Bikini Atoll (http://whc.unesco.org/en/ list/1339/). However, to my reading with reference to the way the nomination dossier relates the Bikini Atoll story (RMI 2009: 42-44, 55), the UNESCO account of the World Heritage metanarrative fixes the heritage values more firmly in the materiality of history and global symbols/ icons. The materiality of history - the sunken fleet, the Bravo bomb crater, and the concrete bunkers as well as the documentary record, evidences the nuclear narrative. The symbols and icons, such as the image of the mushroom cloud, the bikini, Godzilla, and the rise of international movements advocating nuclear disarmament, are global rather than local. In addition the tangible cultural heritage, seen from the gaze of the global NGOs, constructs the material expression of nuclear testing on Bikini Atoll as belonging within this particular landscape/seascape rather than belonging to a people (cf. Greenfield 1989 in Gillman 2010:47).

\section{The slipperiness of local and global, history and prehistory}

Folklorist and anthropologist Phillip McArthur (2008) has examined how Marshall Islanders make sense of their tumultuous, 'ambivalent' and 'destructive-creative' relationship with the United States. He argues that the islanders alternative story to official history (and this includes the world heritage meta-narrative) prompts consideration of the slipperiness of the terms 'local' and 'global'.

To examine the US-RMI relationship, McArthur interrogates the local use of a Marshallese trickster narrative (Letao - 'The Sly One'), a narrative that positions the local at the centre of the global. He relates the episode of the trickster's travels to America to bestow his power on the Americans. McArthur describes this process in the following way (2008:263, 266-267):

The Marshall Islanders playfully dramatize their ambivalent history with Americans through a trickster narrative. By analogy the Americans, with their destructive-creative capacities, draw upon the cosmological power of the Marshallese trickster to become the most powerful and dangerous world chiefs... Thus, instead of positioning the local as invaded and dominated by more centralised structures, ... the Marshallese reverse the order of centralization (which can include globalization) in order to comprehend these structures on their own terms and to place themselves at the centre (Stoeltje and Baumann 1989). They do so through their own prehistorical narrative about their trickster figure ... creative Marshallese draw upon significant meanings and narratives to bypass a national identity and to explore new kinds of transnational values and meanings. 
An important aspect of the narrative of Letao is that it relates to a cosmology of the past, a 'prehistoric' time (in Western terms) before the arrival of Spanish, Germans, Japanese and Americans. This dynamic and mobile Marshallese past 'continues to inform the globally connected present' because it recontexualises the trickster narrative in terms of modern historical events - 'a pre-historical production of the present' (McArthur 2008:267-268, 289). The Latao narrative appears to do more than act as an explanatory framework that weaves together the cosmos and history - it utilises the Indigenous system of meanings to position power at a local level.

The Marshallese are not passive victims of history or ignorant of the realities of global power. As noted by McArthur (2008:281), ' . . the memory of World War II, atomic bomb testing, and continued missile testing at Kwajalein are an indelible part of their experience with Americans.' Marshallese have considerable experience of American culture since many people travel to and from the US in accord with agreed rights under the Compact of Free Association (1986 [2002]). Additionally, the Bikinians have constantly engaged with Americans since 1946 - initially with the US Naval administration (1946-1947), subsequently with the US Trust Territory administration (1947-1986), as well as with the US federal administration and courts from 1975 when a first lawsuit was filed (Niedenthal 2001:12-14). Bikinians are incredibly experienced in world affairs and have regularly visited the US from the 1970s to meet with administrators, lawyers and politicians in relation to seeking, negotiating, and administering compensation packages. In addition, delegations of Bikinians attended the Academy Awards (when the documentary Radio Bikini (Stone 1988) was nominated for best documentary feature) and, also in 1988, a delegation of Bikinians visited Aboriginal groups impacted by British-Australian testing at Maralinga, Australia.

Thus, while worldly lived experience enables Bikinians to recognise their own marginality on the international scene, the Latao narrative simultaneously positions them at the centre of the global. There is a social poetics in this positioning that underpins the status quo between local Bikinians and global political, including World Heritage, actors.

\section{Heritage, rights and resettlement}

I have argued in this paper that the World Heritage Listing of Bikini Atoll for its nuclear test history is based on a cultural engagement between an Indigenous population (through a State Party) and the global NGO UNESCO that mutually benefits and advantages both parties. While Bikini Atoll remains relatively uninhabited and tourism remains small in scale (i.e. the specialised diving enterprise), there is equilibrium in the World Heritage project for both parties derived from the benefits that each receives.

What would be the effect on the symmetry of this relationship if Bikinians were to resettle the atoll? I examine this hypothetical question in order to elicit issues between, and challenges for, the global heritage project and local Indigenous rights. Before doing this, I briefly mention the key challenges to future resettlement of the atoll: radiation and climate change.

Resettlement of Bikini Atoll has, and continues to be, a goal of the Bikinian community. The key obstacle to this occurring has been radiation levels considered to be not 'really safe' (Davis 2005b:213), principally because of the bio-accumulation of radioactive cesium $\left({ }^{137} \mathrm{Cs}\right)$ in terrestrial food sources such as coconuts and coconut crabs. The science and politics of radiation at Bikini Atoll (and the RMI generally) is complex (Robison et al.2009; Robison and Hamilton 2010). For the management of the heritage items this means that there are human health and safety considerations - nuclear test period fallout is essentially co-constituted with the fabric and landscape of nuclear testing. 
Climate change and natural disasters are factors that have considerable potential to impact on an option for permanent re-settlement of Bikini Atoll. The long term impacts of climate change - including sea level rise, increased exposure to storm surge and rising tides, desertification and warmer sea temperatures resulting in erosion, salinisation, decreasing biodiversity and scarcer water supplies (Collett 2009: vii-viii) - have the potential to be catastrophic to the atoll system. Somewhat ironically, natural disasters in the form of storm surges, and more rarely typhoons, are unlikely to impact the sunken ships or Bravo Crater, the physical features most highlighted in the World Heritage nomination.

In March 1946, the number of Bikinians living on Bikini Atoll was 167 (of a total population of 196 - Niedenthal 2001:177). Today the population is over 4,000 (a 'Bikinian' is defined by custom as a person with Bikinian blood or a person married to a Bikinian), a more than 20 times population increase on the 1946 figure. Thus any future resettlement of the atoll could involve a large number of people relative to the past population number. There would likely be a considerable impact on the landscapes, terrestrial habitat, marine resources and nuclear test period heritage features resulting from occupation (e.g. housing, infrastructure, waste and sewage disposal, agriculture and husbandry) and local resource use. The impacts on the nuclear fleet and Bravo Crater resulting from resettlement would, as with climate change impacts, likely be negligible.

A conflict lies however in the conservation and management of Bikini Atoll's marine biodiversity (Pinca et al. 2002), birdlife (Vander Velde and Vander Velde 2003) and terrestrial fauna (e.g. coconut crabs and reptiles). Despite the considerable disturbance of the terrestrial environment caused by the construction of the test site (Fosberg 1988:2 observed that 'no unaltered vegetation has survived'), the bomb blasts, rehabilitation efforts and introduction of invasive species, the relative absence of humans for more than fifty years (following American abandonment after bomb testing ended in 1958) has allowed species to return in considerable number to the atolls. For example, stands of Pisonia grandis are a favourite nesting place for birds (Reimaanlok 2008); the rare and threatened giant clam Tridacna gigas is particularly abundant in Bikini lagoon; there is a high diversity of fish fauna with a high concentration of shark species considered threatened elsewhere; and the recovery of coral reefs within the Bravo Crater provide a rare example of early succession and the development of reef structure (Richards et al. 2008). In brief, Bikini Atoll is home to many species that are threatened or depleted in the rest of Micronesia and the world and the ecological values have global significance (Baker 2010:4). ${ }^{3}$ Bikini Atoll is a living laboratory of island re-colonisation. However, this situation (i.e. the recovery of the 'natural environment' as a 'cultural artefact' deriving from nuclear testing and abandonment) highlights artificiality in the nature/culture dichotomy within the World Heritage Listing criteria.

The Bikinian local government has been active in the protection of the atoll's biodiversity. In July 1997, the KBE LG passed regulations making commercial fishing within 12 nautical miles of the atoll illegal (in line with RMI national regulations), banning the use of gill nets, regulating the taking of lobster, and making fishing for shark and turtles illegal without authorisation. Bird habitats are entirely protected on some islands (Enue to Aeomen islands) and heavily regulated on the remainder ('Bird Islands'). In addition, the World Heritage nomination documents prepared for Bikini Atoll (RMI 2009:26) foreshadow a future re-nomination of the atoll under 'natural' criteria ${ }^{4}$ that would re-categorise the property as either a cultural landscape or mixed cultural and natural site.

\footnotetext{
3 Baker (2010:5) notes: 'The entirety of the Marshall Islands lies in the central-western part of the Conservation International Polynesia/Micronesia Hotspot and the northern Marshall Islands form the Key Biodiversity Area, Kabin Meto.' The 'Micronesian Challenge' is a region-wide initiative aimed at conserving at least 30\% of near-shore marine resources and $20 \%$ of terrestrial resources across Micronesia by 2020 (Beger et al.2008).

4 Criteria (ix): 'Be outstanding examples representing significant ongoing ecological and biological processes in the evolution and development of terrestrial, fresh water, coastal and marine ecosystems and communities of plants and animals.' The criterion refers to the recovery of the marine environment as a result of the bomb detonations and particularly within the Bravo Crater.
} 
Thus the increasingly-recognised ecological importance and values of Bikini Atoll is bringing the place within the purview of regional and global nature conservation agencies and groups. Resettlement of Bikini Atoll would challenge global and regional conservation management goals for both natural and cultural values. There are Indigenous traditions of sustainable use of marine and terrestrial resources controlled by complex social rules in the Marshall Islands (Weissler 2001). However, these customary values and practices have substantially changed as a result of 150 years of colonial entanglement and a transition to cash-based lifestyles. For the Bikinians, a loss of traditional lagoon fishing skills was exacerbated by their removal to the isolated and lagoon-less island of Kili.

A Bikinian homeland resettlement would bring into sharp focus tensions between local Indigenous rights (e.g. Articles 3, 10 and 11 of the United Nations Declaration on the Rights of Indigenous Peoples - United Nations 2007) and the global conservation movement. Issues associated with the tensions between human use of the environment and notions of 'natural' are also evidenced in the case of the semi-nomadic Maasai pastoralists of the Ngorongoro Conservation Area in Tanzania (referenced above). The UN declaration recognises the right of Indigenous peoples to freely pursue economic, social and cultural development (Article 3) and the right to practice and revitalise cultural traditions (Article 11). However, resettlement and development on Bikini Atoll by a relatively large population (i.e. up to 4,000 people today compared to 200 in 1946) would inevitably have impacts on the atoll's marine and terrestrial ecology.

Since global recognition of the ecological values of Bikini Atoll has been foreshadowed and resettlement is a goal of the Bikinian community, there appear to be opportunities for global and local actors to work together to plan for mutually beneficial economic, cultural and conservation outcomes. Environmental and heritage goals might best be achieved through harnessing Indigenous cultural knowledge and western scientific approaches via an approach that supports the rights of Indigenous peoples.

\section{Conclusion}

When I visited Bikini Atoll in September 2009, I was struck by its extent, remoteness and incredible beauty - the colour of the water, the teeming marine life in the shallow lagoon edges, and the closeness to which I was able to get to the birdlife on the outer islands. I was deeply impressed by my Bikinian hosts, not only for their hospitality and generosity in showing me the homeland given up 'for the good of mankind', but also their skill and knowledge - for example, in navigating the atoll and the routes through the coral reefs to access landings on the shores of the many islands. It seemed paradoxical therefore that the reason that Bikini Atoll is inscribed on the world heritage list as centred on the 'monuments' and 'icons' of nuclear testing, including the Bravo crater, the nuclear fleet, the mushroom cloud motif and le bikini, and not for the atoll ecology or knowledge and contemporary lived experiences of the Bikinians.

World Heritage is a strange beast. It manufactures history and heritage at a global scale, and as Sandra Pannell (2006:76) notes: 'World Heritage - as both a global concept and, for some, an imposed process - is subject to negotiation, opposition and a range of accommodations at the local level.' Derek Gillman (2010:1-2, 41-43) describes how the idea of heritage encompasses 'two ways of thinking about cultural property' (Merryman 1986) ' ... represented respectively by cultural cosmopolitans, who seek to promote the idea of 'the heritage of all mankind', and cultural nationalists for whom art, architecture ... are always a part of someone's particular heritage.' Gillman argues there are deep antecedents for the binary created in Western thinking between universalism (the global) and cultural particularism (the local). The World Heritage project (as 
expressed through the 1972 World Heritage Convention) lodges together the 'two ways' (Gillman 2010:49), recognising that the 'World Heritage of mankind as a whole' also belongs to specific people ('to whatever people it may belong') (UNESCO 1972: Preamble).

In its early years, the practice of the World Heritage project had a tendency to work within a Western neo-colonial model (e.g. privileging monuments as well as particular constructions of nature and culture) and to centre power in the global actors (e.g. see Pannell's 2006 discussion of Komodo National Park and Gondwana Rainforest of Australia). In its adoption of the idea of cultural landscapes and striving for a balanced, credible and representative World Heritage List from the early 1990s, the idea of World Heritage saw a marked change in approach through its accommodation of local readings of heritage.

Concerns voiced by global Indigenous peoples NGOs about making the implementation of the World Heritage Convention consistent with the United Nations Declaration on the Rights of Indigenous Peoples is a further challenge to the way World Heritage is constructed and practiced. As at April 2012, the World Heritage List comprised 936 items categorised as cultural (725 of which 66 are cultural landscapes), natural (183) and mixed (28) properties. ${ }^{5}$ The categories themselves still retain a Western construction of nature and culture and this construction is what is being challenged by Indigenous peoples - an idea that the heritage of humans, ecology, landscape, things and history are deeply connected in Indigenous cosmologies.

In this situation, Bikini Atoll Nuclear Test Site, a property which symbolises the dawn of the nuclear age, provides an example of cultural engagement between global/universal and local/ particularist, polarities that can obscure complex processes of creative cooptation (Herzfeld 1997:3) and binary slipperiness. World Heritage Listing has strings attached for those State Parties and local governments who have responsibility for the property (e.g. requirements for state of conservation reporting). But the local administration, such as the KBE LG, has and indeed actively takes the opportunities offered by World Heritage to act back on the global NGOs (UNESCO, ICOMOS, IUCN) and heritage framework. The push for the rights of Indigenous peoples to be foregrounded in the practice of world heritage listing challenges but ultimately can benefit the idea of heritage.

Bikinian people have a long history of political activism concerning restitution for events that can be traced back to Sunday 10 February 1946. Only recently, since the mid-2000s, have the Bikinians coopted the global heritage system as a political tool to continue to expose the local and continuing consequences of nuclear testing. Thus Bikinians have enmeshed World Heritage in the politics of Indigenous rights in a way that Indigenous rights, for example the living cultural values of the Maasai resident population in the Ngorongoro Conservation Area, has seldom been integrated into global heritage. Bikini Atoll makes the politics of Indigenous heritage rights visible in World Heritage, highlighting the tensions between official heritage practice and the lived experience of local actors. And that is social poetics.

\section{Acknowledgements}

Deputy Mayor Wilson Note, Councillor Banjo Joel, Jack Niedenthal, Lani Kramer, Edward Maddison and Jim McNutt were my generous hosts, guides and companions on Bikini Atoll. My visit to the atoll was organised through the World Heritage Unit, Paris. I thank the two referees for the paper for their insightful comments and feedback. Finally I thank the editors of the volume, Denis Byrne, Sally Brockwell and Sue O’Connor for their input and support.

5 The nuclear landscapes/places on the list comprise the Hiroshima Peace Memorial (Genbaku Dome), Japan (listed 1996), and Bikini Atoll Nuclear Test Site. 


\section{References}

Baker, N. 2010. Bikini Atoll conservation management plan. Kili-Bikini-Ejit Local Government, Majuro.

Barker, H.M. 2004. Bravo for the Marshallese: Regaining control in a post-nuclear, post-colonial world. Thompson and Wadsworth, Belmont.

Beger, M., Jacobson, D., Pinca, S., Richards, Z., Hess, D., Harriss, F., Page, C., Peterson, E. and Baker, N. 2008. The state of coral reef ecosystems of the Republic of the Marshall Islands. In: Waddell, J.E. and Clarke, A.M. (eds), The state of coral reef ecosystems of the United States and Pacific Freely Associated States, pp. 387-418. NOAA/NCCOS Centre for Coastal Monitoring and Assessment's Biogeography Team, Silver Spring.

Blake, J. 2009. UNESCO's 2003 Convention on Intangible Cultural Heritage: The implications of community involvement in 'safeguarding'. In: Smith, L. and Akagawa, N. (eds), Intangible heritage, pp. 45-65. Routledge, New York.

Bradley, D. 1946/1984. No place to hide. University Press of New England, Armidale.

Brown, S. 2013. Archaeology of brutal encounter: Heritage and bomb testing on Bikini Atoll, Republic of the Marshall Islands. Archaeology in Oceania, 48(1):26-39.

Carucci, L.M. 1997. Nuclear nativity: Rituals of renewal and empowerment in the Marshall Islands. Northern Illinois University Press, Deklab.

Cleere, H. 2001. The uneasy bedfellows: Universality and cultural heritage. In: Layton, R., Stone, P.G., and Thomas, J. (eds), Destruction and conservation of cultural property, pp. 22-29. Routledge, London.

Collett, L. 2009. A fair-weather friend? Australia’s relationship with a climate changed Pacific. Paper No.1. The Australian Institute, Canberra.

Davis, J.S. 2005a. Representing place: 'Deserted isles' and the reproduction of Bikini Atoll. Annals of the Association of American Geographers 95(3):607-625.

Davis, J.S. 2005b. 'Is it really safe? That's what we want to know': Science, stories and dangerous places. The Professional Geographer 57:213-221.

de Groot, G.J. 2006. The bomb: A life. Harvard University Press, Cambridge.

Delgado, J.P. 1996. Ghost fleet: The sunken ships of Bikini Atoll. University of Hawai'i Press, Honolulu.

Delgado, J.P., Lenihan, D.J. and Murphy, L.E. 1991. The archaeology of the atomic bomb: A submerged cultural resources assessment of the sunken fleet of operation crossroads at Bikini and Kwajalein Atoll lagoons, Republic of the Marshall Islands. Submerged Resources Centre Professional Report No. 11. US National Park Service, Santa Fe.

Fosberg, F.R. 1988. Vegetation of Bikini Atoll, 1985. Atoll Research Bulletin 315:1-28.

Gillman, D. 2010. The idea of cultural heritage. Cambridge University Press, New York.

Herzfeld, M. 1997. Cultural intimacy: Social poetics in the Nation-State. Routledge, London.

Holmes and Harver Inc. 1988. Bikini Island Wato diagram, Bikini Atoll masterplan. Unpublished report. Holmes and Harver Inc., Albuquerque.

International Work Group for Indigenous Affairs. 2011. Joint Statement on continuous violations of the principle of free, prior and informed consent in the context of UNESCO's World Heritage Convention.

Keever, B.A.D. 2004. News zero: The New York Times and the bomb. Common Courage Press, Monroe.

Kiste, R.C. 1974. The Bikinians: A study in forced migration. Cummings Publishing. Menlo Park. 
Mason, L. 1950. The Bikinians: a transplanted population. Human Organisation 9(1):5-15.

Mason, L. 1954. Relocation of the Bikinian Marshallese: A study in group migration. University of Hawaii Press, Honolulu.

McArthur, P.H. 2008. Ambivalent fantasies: local prehistories and global dramas in the Marshall Islands. Journal of Folklore Research 45(3):263-298.

Merryman, J.H. 1986. Two ways of thinking about cultural property. American Journal of International Law 80:831-853.

Niedenthal, J. 1997. A history of the people of Bikini following nuclear weapons testing in the Marshall Islands: With recollections and views of Elders of Bikini Atoll. Health Physics 73(1):28-36.

Niedenthal, J. 2001. For the good of mankind: A history of the people of Bikini and their islands. Bravo Publishers, Majuro.

Niedenthal, J. 2011. World's debt to Bikini recognised: nuclear test site added to Heritage List. Voices UNESCO in the Asia-Pacific 25(1):10-11.

Pannell, S. 2006. Reconciling nature and culture in a global context? Lessons from the World Heritage List. Research Report. James Cook University, Cairns.

Pinca, S., Beger, M., Richards, Z. and Peterson, E. 2002. Coral reef biodiversity community-based assessment and conservation planning in the Marshall Islands: Baseline surveys, capacity building and natural protection and management of coral reefs of the atolls of Bikini and Rongelap. Report to the Rongelap Government, Republic of the Marshall Islands.

Reimaanlok National Planning Team. 2008. Reimaanlok: National conservation area plan for the Marshall Islands. N. Baker, Melbourne.

Republic of the Marshall Islands. 2009. Bikini Atoll: Nomination by the Republic of the Marshall Islands for inscription on the World Heritage List 2010. Republic of the Marshall Islands, Majuro.

Richards, Z., Beger, M., Pinca, S. and Wallace, C.C. 2008. Bikini Atoll coral biodiversity resilience revealed: five decades after nuclear testing. Marine Pollution Bulletin 56:503-515.

Robison, W.L., Brown, P.H., Stone, E.L., Hamilton, T.F., Conrado, C.L. and Kehl, S. 2009. Distribution and ratios of ${ }^{137} \mathrm{Cs}$ and $\mathrm{K}$ in control and $\mathrm{K}$-treated coconut trees at Bikini Island where nuclear test fallout occurred: effects and implications. Journal of Environmental Radioactivity $100: 76-83$.

Robison, W.L. and Hamilton, T.F. 2010. Radiation doses for Marshall Island's atolls affected by U.S. nuclear testing: All exposure pathways, remedial measures, and environmental loss of ${ }^{137} \mathrm{Cs}$. Health Physics 98(1):1-11.

Simon, S. 1997. A brief history of people and events related to atomic testing in the Marshall Islands. Health Physics 73(1):5-20.

Smith, A. 2007. Colonialism and the bomb in the Pacific. In: Schofield, J. and Cocroft, W. (eds), $A$ fearsome heritage: Diverse legacies of the Cold War, pp. 51-72. Left Coast Press, Walnut Creek.

Smith, A. and Jones, K.L. 2007. Cultural landscapes of the Pacific Islands: ICOMOS thematic study. UNESCO World Heritage Centre, Paris.

Smith, L. 2006. Uses of heritage. Routledge, London.

Spennemann, D.H.R. 1990. The ownership of cultural resources in the Marshall Islands: An essay in pertinent jurisprudence and legal history. Alele Corporation, Majuro. 
Spennemann, D.H.R. 2000. Cultural heritage legislation in the Republic of the Marshall Islands. Historic Preservation Act of 1991, Republic of the Marshall Islands.

Spennemann, D.H.R. and D. Look. 2006. Impact of tropical vegetation on World War II-era cultural resources in the Marshall Islands. Micronesian Journal of the Humanities and Social Sciences 5(1/2):440-462.

Stone, R. 1988. Radio Bikini. (Documentary Film, Director: Robert Stone).

Tobin, J.A. 1953. The Bikini People, past and present. Unpublished report. Marshall Islands District, Majuro.

United Nations. 2007. United Nations Declaration on the Rights of Indigenous Peoples.

UNESCO. 1972. Convention Concerning the Protection of the World Cultural and Natural Heritage. UNESCO, Paris.

UNESCO World Heritage Centre. 2004. The State of World Heritage in the Asia-Pacific Region. World Heritage Reports 12. UNESCO, Paris.

UNESCO World Heritage Centre. 2008. Operational Guidelines for the Implementation of the World Heritage Convention. UNESCO, Paris.

United Nations Permanent Forum on Indigenous Issues. 2011. Report on the Tenth Session (16-27 May 2011).

US Department of the Interior. 1986. Compact of Free Association Act of 1985. U.S. Public Law 99-239 - Jan.14, 1986.

Vander Velde, N. and Vander Velde, B. 2003. A review of the birds of Bikini Atoll, Marshall Islands with recent observations. Unpublished report. Bikini Atoll Local Government, Majuro.

Weisgall, J.M. 1980. The nuclear nomads of Bikini. Foreign Affairs 39:74-98.

Weisgall, J.M. 1994. Operation crossroads: the atomic tests at Bikini Atoll. Naval Institute Press, Annapolis.

Weissler, M.I. 2001. Precarious landscapes: prehistoric settlement in the Marshall Islands. Antiquity 75:31-32.

Williamson, R.V. 2001. The challenges of survey and site preservation in the Republic of the Marshall Islands. Cultural Resource Management 1:44-45.

World Heritage Committee. 1994. Expert Meeting on the 'Global Strategy' and thematic studies for a representative World Heritage List. UNESCO, Paris.

World Heritage Committee. 2011. Decisions Adopted by the World Heritage Committee at its 35th Session (UNESCO 2011).

Zinn, H. 2010. The bomb. City Lights Books, San Fransisco. 